\title{
電子情報通信学会 情報・システムソサイエティ誌編集委員会
}

副会長（編集会議担当）

山名 早人 (早大 yamana@acm.org)

-編集委員長

門田 啓（NEC a-monden@bk.jp.nec.com）

-編集幹事

坪下幸宽

（富士ゼロックス Yukihiro.Tsuboshita@fujixerox.co.jp）

篠崎 隆宏（東工大 shinot@ip.titech.ac.jp）

-企画広報幹事

秋山達勇（NEC t-akiyama@df.jp.nec.com）
•特任編集幹事

菅谷 史昭（KDDI 研 fsugaya@kddilabs.jp）

松居 辰則（早大 matsui-t@waseda.jp）

松井 知子 (統数研 tmatsui@ism.ac.jp)

山川宏(ドワンゴ hiroshi_yamakawa@dwango.co.jp)

宮崎修一（京大 shuichi@media.kyoto-u.ac.jp）

西脇 大輔（NEC d_nishiwaki@da.jp.nec.com）

神原 誠之（奈良先端大 kanbara@is.naist.jp）

・和文論文誌編集副委員長

潮田 明 (Japio aushioda@mbr.nifty.com)

- 英文論文誌編集幹事

山下幸彦（東工大 yamasita@ide.titech.ac.jp）

・知能ソフトウェア工学 (KBSE)

研究専門委員会

青木 善貴

（日本ユニシス yoshitaka.aoki@unisys.co.jp）

- 音声 $(\mathrm{SP})$

研究専門委員会

篠崎 隆宏（東工大 shinot@ip.titech.ac.jp）

- 教育工学 (ET)

研究専門委員会

東本 崇仁（東京工芸大 t.tomoto@cs.t-kougei.ac.jp）

- 医用画像 (MI)

研究専門委員会

平野靖（山口大 yhirano@yamaguchi-u.ac.jp）

・ソフトウェアインタプライズモデリング (SWIM)

研究専門委員会

宇田川 佳久

（東京工芸大 udagawa@cs.t-kougei.ac.jp)

・リコンフィギャラブルシステム（RECONF） 研究専門委員会

宮島 敬明 (JAXA miyajima.takaaki@jaxa.jp)

- 情報論的学習理論と機械学習 (IBISML)

研究専門委員会

鈴木 大慈（東工大 s-taiji@is.titech.ac.jp）

・マルチメディア情報ハイディング・エンリッチメント 研究専門委員会

市野 将嗣（電通大 ichino@inf.uec.ac.jp）

・クラウドネットワークロボット (CNR)

研究専門委員会

神原 誠之(奈良先端大 kanbara@is.naist.jp)

・サービスコンピューティング (SC)

研究専門委員会

田仲 正弘 (NICT mtnk@nict.go.jp)

・サイバーワールド $(\mathrm{CW})$

時限研究専門委員会

河野 義広（東京情報大 ykawano@rsch.tuis.ac.jp）

・再生可能集積システム（RIS）

時限研究専門委員会

森 秀樹（明治大 himori@meiji.ac.jp）

編集後記 著者の皆様には，お忙しい中，多様かつ創意に富んだ原稿を執筆頂き，大変ありがとうございま した，読者の皆様にとってより有意義な雑誌となるよう誌面を充実させていく予定ですので，これからも本 誌をよろしくお願いいたします（主担当：ホットリンク 榊）著者の皆様には迅速な対応をして頂き，ス ムーズに発行できたことを感謝申し上げます，編集委員会では，多様な分野の方々とお話しする機会もあり， 大変勉強になりました。今回 80 号ということで，本誌のますますの発展を㧍祈りしております（副担当： 大妻女子大 藤村) 